\title{
Eksistensi Pendidikan Islam Al-Azhar: Sejarah Sosial Kelembagaan al-Azhar dan Pengaruhnya terhadap Kemajuan Pendidikan Islam Era Modernisasi di Mesir
}

\author{
SYAHRAINI TAMBAK \\ Fakultas Agama Islam (FAI) Universitas Islam Riau (UIR) Pekanbaru \\ Jl. Kaharuddin Nasution, No. 113, Perhentian Marpoyan Pekanbaru 28284 \\ e-mail: syahraini_tambak@yahoo.co.id
}

\begin{abstract}
Abstrak: Perkembangan pendidikan islam al-Azhar tak luput dari pengaruh sejarah sosial yang terkait pada masa itu. Adapun sejarah sosial pendidikan Islam era reformasi dan modern di al-Azhar dapat disimpulkan dalam beberapa hal. Pertama, latar belakang sosial al-Azhar. Dinasti Fatimiyah menjadikan Mesir sebagai pusat pemerintahan. Kemudian berdiri pula Dinasti Ayyubiyah di Mesir yang berpaham Sunni berdampak bagi perkembangan Al-Azhar. Di samping itu muncul pula Napoleon Bonaparte yang kemudian menguasai Mesir yang turut berdampak bagi perkembangan Al-Azhar. Kedua, latar belakang terjadinya pembaruan di Al-Azhar karena; bergesernya paham rasional Syi'ah pada ortodoksi ideologi Sunni; invasi Napoleon Bonaparte dari Prancis yang mengalahkan Kerajaan Turki Usmani di Mesir dalam waktu yang cepat; dan persentuhan peradaban Prancis yang dibawa Napoleon pada pendidikan di AlAzhar. Ketiga, tokoh dan ide pembaruan di Al-Azhar di Mesir dipelopori oleh Muhammad Ali Pasya, Muhammad Abduh, dan Muhammad Rasyid Ridha yang berusaha melukakan reformasi dan modernisasi di Al-Azhar dengan mamasukkan kurikulum-kurikulum dari Barat. Umat Islam dalam pandangan mereka harus keluar dari ketertinggalan melalui pembukaan kembali pemikiran rasional dan membuka diri terhadap peradaban modern yang ada di Barat seperti yang dibawa oleh Napoleon Bonaparte dari Prancis.
\end{abstract}

Kata kunci: Sejarah sosial, pengaruh sejarah sosial, pendidikan Islam al-Azhar

\section{PENDAHULUAN}

Pada dasarnya pendidikan Islam merupakan sarana terpenting untuk membawa manusia mencapai tujuan hidupnya. Melalui pendidikan, kehidupan individu dapat menjadi suatu pribadi yang mampu berdiri sendiri dan berinteraksi dalam kebersamaan dengan orang lain secara konstruktif. Pendidikan mampu membentuk dan membangun sebuah peradaban yang agung pada zamannya.
Pada masa Daulah Fatimiyah di Mesir (Sihbudi, 1993: 81-82), pendidikan Islam berkembang dengan pesat dan maju. Al-Azhar pada masa Dinasti Fatimiyah merupakan lembaga pendidikan Islam yang memberikan kontribusi nyata pada dunia pendidikan Islam pada masa itu. Pada masa itu alAzhar mampu melahirkan tokoh-tokoh pendidikan Islam yang menjadi pemegang tampuk kepemimpinan di alAzhar serta dunia dan memberikan 
konstruksi pemikiran hingga kini dapat dijadikan referensi (Amaliyah, 2013: 101-111).

Islam memiliki sifat universal dan kosmopolit yang dapat merambah ke ranah kehidupan apa pun, termasuk dalam ranah pendidikan (Razak, 1989: 56-57). Ketika Islam dijadikan sebagai paradigma ilmu pendidikan, paling tidak berpijak pada tiga alasan. Pertama, ilmu pendidikan sebagai ilmu humaniora tergolong ilmu normatif, karena ia terkait oleh norma-norma tertentu. Pada taraf ini, nilai-nilai Islam sangat berkompoten untuk dijadikan norma dalam ilmu pendidikan. Kedua, dalam menganalisis masalah pendidikan, para ahli selama ini cenderung mengambil teori dan falsafah pendidikan Barat. Falsafah pendidikan Barat lebih bercorak sekuler yang memisahkan berbagai dimensi kehidupan, sedangkan masyarakat Muslim lebih bersifat religius. Atas dasar ini, nilai-nilai ideal Islam sangat memungkinkan untuk dijadikan acuan dalam mengkaji fenomena kependidikan. Ketiga, dengan menjadikan Islam sebagai paradigma, keberadaan ilmu pendidikan memiliki ruh yang dapat menggerakkan kehidupan spiritual dan kehidupan yang hakiki (Mujib \& Mudzakkir, 2008: 1-2).

Konsep pendidikan Islam pada hakikatnya berupaya menjadikan manusia mencapai keseimbangan kepribadiannya secara menyeluruh, dan dilakukan melalui tahapan tertentu. Rumusan pendidikan Islam harus dikaitkan dengan pemikiran filosofis dan sejarah sosial pendidikan Islam. Pendidikan Islam dibangun di atas konstruksi wahyu al-Quran dan Sunnah sebagai sumber utamanya. Pendidikan Islam juga memiliki asas dan landasan hukum yang tetap terbangun dari kedua sumber utama tersebut. Pendidikan Islam dari masa ke masa, mulai dari zaman Rasulullah SAW Khulafa alRasyidin sampai terbentuknya Daulah Umayyah dan Daulah Abbasiyah hingga sekarang telah memberikan konstribusi nyata bagi perkembangan dunia, khususnya umat Islam itu sendiri. Afrika Utara sampai tahun $850 \mathrm{M}$ dikuasai oleh Bani Aghlab, meliputi wilayah Ifriqiyah (Tunisia) dan sebagian Pulau Sisilia, merupakan negara bagian Daulah Abbasiyah. Wilayah sebelah baratnya berkuasa Bani Rustamiyah di Aljazair dan Bani Idris di Maroko, sedangkan Spanyol berada di bawah kekuasaan Bani Umayyah. Namun sesudah tahun 909 muncul sebuah dinamika baru, terbentuknya sebuah negara Fatimiyah di Tunisia (Sunanto, 2007: 141).

Dinasti Fatimiyah adalah Dinasti Syi'ah yang berkuasa dari 909 M (296 H) sampai dengan $1171 \mathrm{M}(569 \mathrm{H})$ atas dasar legitimasi klaim keturunan Nabi SAW lewat Fatimah dan Hadzrat Ali dari Ismail anak Jafar Sidik, keturunan keenam dari Ali. Dinasti ini didirikan sebagai tandingan bagi penguasa dunia muslim saat itu yang terpusat di Baghdad, yaitu Bani Abbasiyah (Hitti, 2008: 787). Wilayah kekuasaan Dinasti Fatimiyah meliputi Afrika Utara, Mesir, dan Suriah. Berdirinya Dinasti Fatimiyah dilatarbelakangi oleh melemahnya Dinasti Abbasiyah. Ubaidillah al-Mahdi mendirikan Dinasti Fatimiyah yang lepas dari kekuasaan Abbasiyah (Amin, 2009: 254).

$$
\text { Masa kegemilangan Dinasti }
$$
Fatimiyah ditandai dengan berpindahnya pusat pemerintahan ke Kairo. Setelah Kairo berdiri dan dilengkapi dengan berbagai sarana termasuk masjid al-Azhar yang kemudian dijadikan pusat Perguruan Tinggi Islam oleh Khalifah Fatimiyah alAziz (975 M- 996 M). Jauhar juga mendirikan Dar al-Hik-mah di tahun 1005 M. Kemudian Dinasti Fatimiyah yang ditopang dengan wilayah 
pengaruhnya yang luas mampu membangkitkan berbagai kegiatan ilmiah, perdagangan, dan keagamaan.

Semenjak abad ke-10 pada masa Dinasti Fatimiyah yang membangun institusi pendidikan yang sekarang dikenal dengan nama Universitas AlAzhar, Mesir menjadi pusat peradaban dan pengembangan ilmu-ilmu keislaman. Ribuan tahun Sebelum Masehi, negara para Pharao ini telah menjadi pusat peradaban dunia, di samping peradaban lain seperti Mesopotamia dan Bizantium. Tiap peradaban yang maju, pasti disokong oleh luhurnya ilmu pengetahuan dari manusia yang memiliki peradaban tersebut. Artinya hanya bangsa dengan ilmu pengetahuan yang tinggi akan mampu sampai pada peradaban yang mulia (Nata, 2004: 87).

Kemajuan ilmu pengetahuan dan teknologi modern memasuki dunia Islam, terutama sesudah pembukaan abad ke-19 M, yang dalam sejarah Islam dipandang sebagai permulaan periode modern. Kontak dengan dunia Barat selanjutnya membawa ide-ide baru ke dunia Islam seperti rasionalisme, nasionalisme, demokrasi dan sebagainya. Semua ini menimbulkan persoalan-persoalan baru, dan pemimpin-pemimpin Islam pun mulai memikirkan cara mengatasi persoalan itu.

Tulisan singkat ini secara spesifik mengetengahkan ulasan tentang; Sejarah sosial lembaga pendidikan AlAzhar; Latar belakang terjadinya pembaruan di Al-Azhar; dan tokoh serta ide pembaruan pada lembaga pendidikan al-Azhar. Kajian terhadap tiga persoalan ini diharapkan dapat memberikan sekelumit kontribusi bagi pemahamahan tentang sejarah sosial pendidikan Islam tentang lembaga pendidikan al-Azhar era modernisasi di dunia Islam.
KONSEP TEORI

\section{Sejarah Sosial Lembaga Pendidikan al-Azhar \\ Dinasti Fatimiyah Menjadikan Mesir sebagai Pusat Pemerintahan}

Sejarah berdirinya Universitas AlAzhar tidak terlepas dari berdirinya suatu Dinasti Fatimiyah yang merupakan satu-satunya Dinasti Syiah dalam Islam. Dinasti Fatimiyah didirikan di Tunisia pada tahun $909 \mathrm{M}$ sebagai tandingan dari Daulah Bani Abbasiyah yang berpusat di Baghdad dengan khalifah pertama Said bin Husain yang bergelar Ubaidillah alMahdi (Thohir, 2009: 113).

Ketika Dinasti Abbasiyah mengalami kemunduran dalam berbagai hal, di Afrika Utara berdiri sebuah dinasti yang bernama Dinasti Fatimiyah. Dinasti ini didirikan atas idealisme orang-orang Syi'ah, karena mereka beranggapan bahwa yang berhak menjadi pemimpin (imamah) sebagai pengganti Rasulullah SAW ialah keturunan Fathimah putri Rasulullah SAW (Zulkarnaini, 2011: 1). Sebenarnya dari golongan Syi'ah sudah lama ingin menjadi penguasa yaitu ketika Khalifah Ali bin Abi Thalib jatuh dari kepemimpinan akan tetapi pada masa Daulah Umayyah dan Abbasyiah mereka tidak berhasil untuk memangku jabatan pemimpin karena selalu mendapat tekanan politik. Akan tetapi Syi'ah ini adalah bukan kelompok yang mudah menyerah begitu saja, mereka selalu mengadakan gerakan-gerakan akan tetapi gerakan mereka bersifat taqiyah, pura-pura patuh terhadap penguasa akan tetapi mereka secara diam-diam menyusun kekuatan. Dinasti ini berdiri diantara dua kekuatan besar yaitu Dinasti Abbasiyah di Damaskus dan Dinasti Umayyah di Spanyol.

Invansi yang dilakukan oleh Dinasti Fatimiyah berhasil menaklukkan Mesir dibawah pimpinan 
panglima perang Jawhar al-Shaqoly. Dinasti Fatimiyah berdiri tahun 297567/909-1171 semula di Afrika Utara, kemudian di Mesir. Dinasti ini beraliran Syi'ah Ismailiyah dan pendirinya Ubaidillah al-Mahdi yang datang dari Syiria ke Afrika Utara menisbahkan nasabnya pada Fathimah binti Rasullulah SAW istri Ali bin Abi Thalib.

\section{Ketika Bani Fatimiyah yang} berkuasa di Afrika Utara sekitar 60 tahun, sebelum kemudian pindah ke Mesir tahun $973 \mathrm{M}$, juga telah memberikan sumbangan yang tidak kecil terhadap perkembangan peradaban di daerah itu. Salah satu peninggalan terbesar bagi peradaban Islam yang dicapai adalah Perguruan Tinggi (masjid) al-Zaitun. Universitas yang berada di Tunisia itu merupakan universitas tertua di dunia Islam berdiri tahun $976 \mathrm{M}$, akan tetapi pembangunan universitas itu sesungguhnya dilaksanakan setelah pusat pemerintahan Fatimiyah pindah ke Mesir. Peninggalan peradaban Kota Kairo dibangun pada tanggal 17 Sya'ban 358 H/969 M oleh panglima perang Dinasti Fatimiyah yang beraliran Syi'ah, Jawhar alShaqoly, atas perintah Khalifah Fatimiyah, al-Mu'iz Lidinillah (953-975 M), sebagai ibu kota kerajaan dinasti tersebut, bentuk kota ini hampir merupakan segi empat (Yatim, 1995: 35-37).

Pada 24 Jumadil Ula tahun $359 \mathrm{H} /$ April 970 M, Jawhar mendirikan sebuah Masjid Agung al-Azhar dan peresmiannya ditandai dengan shalat Jum'at pertama pada tanggal 6 Ramadhan $361 \mathrm{H}$ dan yang bertindak sebagai khatib adalah Abu Hasan alKhairawan seorang qodhi terkenal pada masa pemerintahan al-Mansur ('Auf, 1970: 19). Pembangunan masjid ini diselesaikan pada 17 Ramadhan 361 H/22 Juni 972 M yang mana pembangunannya memakan waktu 2 tahun, yang kemudian berkembang menjadi sebuah Universitas Al-Azhar ternama hingga kini (Jamal, 1988: 11).

Masjid al-Azhar terletak di Tenggara Kota Kairo, ini mengalami pengembangan sebagai tempat melakukan propaganda ajaran Syi'ah dan lambang kepemimpinan spiritual umat Islam. Masjid ini dikembangkan fungsinya akibat banyaknya para pelajar yang ingin mendalami ilmu agama dan berdiskusi, maka timbul inisiatif untuk mengembangkan masjid ini menjadi sebuah universitas yang merupakan dasar yang sangat fundamental dalam membangun paradigma pemikiran keislaman (Hitti, 2005: 790).

Pada masa-masa awal, proses pendidikan Islam berlangsung di tempat-tempat yang merupakan pusat ibadah, yaitu masjid (Antonio, 2009: 196). Namun karena banyaknya umat Islam yang berminat untuk belajar sedangkan kapasitas masjid tidak lagi mencukupi, juga mengganggu kegiatan orang-orang yang beribadah, institusi pendidikan mulai mengadakan pembenahan-pembenahan (Nata, 2004: 87).

Ibnu Killis adalah salah seorang tokoh dan pelopor perkembangan pendidikan pada kekhalifahan Fatimiyah di Mesir, ia mendirikan sebuah universitas dan menghabiskan ribuan dinar perbulan untuk membiayainya. $\mathrm{Di}$ bawah kekuasaannya, tersebutlah seorang dokter yang sangat terkenal bernama Muhammad al-Tamim, yang lahir di Yerussalem dan pindah ke Mesir sekitar tahun 970 M. Salah satu fondasi terpenting yang dibangun pada masa Fatimiyah adalah pembangunan Dar alHikmah (rumah kebijaksanaan) atau Dar al-'Ilm (rumah ilmu) yang didirikan oleh al-Hakim pada tahun 1005 sebagai pusat pembelajaran dan penyebaran ajaran Syi'ah ekstrim (Hitti, 2005: 788). 
Perpustakaan Dar al-Hikmah di Kairo ini didirikan oleh al-Hakim Biamrillah. Perpustakaan ini dibuka pada tanggal 10 Jumadil Akhir tahun $395 \mathrm{H}$, setelah dilengkapi perabotan dan hiasan. Pada semua pintu dan lorongnya dipasangi tirai. $\mathrm{Di}$ perpustakaan tersebut ditempatkan para penanggung jawab, karyawan, dan petugas. Dihimpun pula buku-buku yang belum pernah dihimpun oleh seorang raja pun. Perpustakaan itu mempunyai 40 lemari. Salah satu lemari memuat 18.000 buku tentang ilmu-ilmu kuno. Semua orang boleh masuk ke perpustakaan tersebut. Di antara mereka ada yang datang untuk membaca buku, menyalin, atau belajar. Di tempat tersebut terdapat segala sesuatu yang diperlukan oleh pengunjung (tinta, pena, kertas, dan tempat tinta) (Nata, 2004: 88).

Untuk mengembangkan institusi ini, al-Hakim mengeluarkan dana sebesar 257 dinar di antaranya digunakan untuk menyalin berbagai naskah, memperbaiki buku, dan pemeliharaan umum lainnya. Gedung ini dibangun berdekatan dengan istana kerajaan yang di dalamnya terdapat sebuah perpustakaan dan ruang-ruang pertemuan. Kurikulumnya meliputi kajian tentang ilmu-ilmu keislaman, astronomi, dan kedokteran (Nata, 2004: 88).

Pada masa al-Mustanshir, kegagalan atau kemunduran kerajaan yang meng-akibatkan berkurangnya harta kekayaan, pada gilirannya menyebabkan kemunduran lebih besar dengan banyaknya buku-buku yang hilang dari perpustakaan kerajaan. Perpustakaan itu sendiri mulai didirikan pada masa al-Aziz, ketika itu memiliki kurang lebih 200.000 buku dan 2.400 eksemplar al-Quran yang dihiasi ornamen-ornamen indah. Salah satu koleksi langka perpustakaan ini adalah naskah-naskah hasil karya Ibn
Muqlah dan ahli-ahli kaligrafi lainnya. Di perpustakaan ini pula al-'Aziz menyimpan salinan tulisan tangan untuk buku sejarah karya al-Thabari. Pengganti al-Mustanshir membangun kembali sebuah perpustakaan. Ketika satu abad kemudian Shalahuddin menguasai istana kerajaan, perpustakaan istana itu masih menyimpan sekitar 100.000 jilid buku, sebagian dari buku-buku itu disertai harta rampasan lainnya dibagikan kepada bawahannya.

Masjid al-Azhar adalah pusat ilmu pengetahuan, tempat diskusi bahasa dan juga mendengarkan kisah dari orang yang ahli bercerita. Masjid ini sebenarnya diperuntukkan bagi Dinasti Fatimiyah yang sedang bersaing dengan kekhalifahan di Baghdad. Usaha yang dilakukannya ialah dengan mengajarkan Mazhab Syi'ah kepada kader-kader mubaligh yang bertugas meyakinkan masyarakat akan kebenaran mazhab yang dianutnya. Ia merupakan lembaga Fatimiyah sebagai pusat latihan kader penyebar ideologi Syi'ah yang mengancam otoritas Abbasiyah Sunni. Maka Dinasti Saljuk Abbasiyah mendirikan lembagalembaga pendidikan teologi ortodoks sebagai upaya mengimbangi upaya alAzhar (Mughni, 1997: 13-14). Sebagai sebuah gerakan politik dan keagamaan, Khalifah Fatimiyah menaruh perhatian khusus atas penyebaran doktrindoktrin tertentu (dakwah Fatimiyah) melalui para "kader" (da'i). Program yang dilontarkan kaum Fathimiyyin meliputi dua tahap: tahap pertama, pelaksanaan pengajaran serta pembentukan undang-undang; tahap kedua, dakwah secara rahasia (Nata, 2004: 92).

Untuk memenuhi kebutuhan terhadap tenaga para da'i inilah alAzhar kemudian ditingkatkan peranannya bukan hanya sebagai masjid melainkan juga sebagai lembaga 
pendidikan yang terorganisir di bawah pengawasan khalifah. Al-Azhar pada masa Dinasti Fatimiyah merupakan lembaga pendidikan yang menjadi corong dan alat untuk propaganda kekuasaan kekhalifahan, sekaligus sebagai alat penyebaran doktrin ajaran Syi'ah. Al-Azhar tampak berbeda dengan madrasah sebelumnya. Pada lembaga ini sudah dilengkapi dengan asrama untuk guru-guru dan para mahasiswa, juga aula besar (iwan) yang dipergunakan untuk kuliah umum. Iwan merupakan bagian yang sangat penting bagi al-Azhar. Pelaksanaan proses belajar mengajar di al-Azhar mengacu kepada aturan-aturan yang ditetapkan oleh pengelola madrasah.

Al-Azhar pada masa Dinasti Fatimiyah merupakan lembaga pendidikan yang menjadi corong dan alat untuk propaganda kekuasaan kekhalifahan, sekaligus sebagai alat penyebaran doktrin ajaran Syi'ah. Pada masa itu, sistem pengajaran terbagi menjadi empat kelas, yaitu: Pertama, kelas umum diperuntukkan bagi orang yang datang ke al-Azhar untuk mempelajari al-Quran dan penafsirannya; Kedua, kelas para mahasiswa Universitas al-Azhar kuliah dengan para dosen yang ditandai dengan mengajukan pertanyaan dan mengkaji jawabannya; Ketiga, kelas Darul Hikam, kuliah formal ini diberikan oleh para mubaligh seminggu sekali pada hari Senin yang dibuka untuk umum dan pada hari Kamis dibuka khusus untuk mahasiswa pilihan. Keempat, kelas nonformal, yaitu kelas untuk pelajar wanita (Nata, 2004: 92).

\section{Dinasti Ayyubiyah dengan Paham Sunni}

Perubahan orientasi al-Azhar terjadi menyusul ambruknya kekhalifahan Fatimiyah di Kairo. Setelah hampir 200 tahun digunakan
Bani Fatimiyah sebagai basis pendidikan dan penyebaran doktrindoktrin Syi'ah, al-Azhar diambil alih Salahuddin Yusuf al-Ayyubi untuk dijadikan madrasah-masjid yang berorientasi Sunni. Berlainan dengan Bani Fatimiyah yang menekankan pengajaran filosofis dan teologis, Dinasti Ayyubiyah (Ash-Shayim, 2003: 30), sebagaimana penguasa dan pemuka Sunni yang lain, lebih mementingkan pengajaran fikih dalam madrasah yang mereka kelola, termasuk al-Azhar. Pengambil-alihan ini, sebenarnya telah mereduksi posisi al-Azhar yang berorientasi supralokal menjadi lembaga yang berwawasan sempit dikarenakan lingkup politik Dinasti Ayyubiyah yang bercorak lokal. Hanya karena peranan Kairo yang strategis dalam perjalanan sejarah Islam akhirnya bisa diperoleh kembali dan dipertahankan, khususnya pada zaman modern.

Setelah al-Ayyub menaklukkan Mesir tahun $1171 \mathrm{M}$ selama hampir satu abad dari tahun 1171-1267 M, alAzhar dikosongkan. Pada abad kekosongan itu salat Jumat di masjid alAzhar pun dilarang dan pindah ke masjid al-Hakim, karena mereka berpemahaman tidak boleh ada dua khutbah di dalam satu kota. Semenjak itulah Dinasti Fatimiyah berakhir sehingga al-Azhar berubah menjadi universitas Sunni.

Pendiri Dinasti Ayyubiyah adalah Salahudin Yusuf al-Ayyubi. Dinasti ini berdiri menggantikan kekuasaan Dinasti Fatimiyah. Dinasti Fatimiyah runtuh ketika kekhalifahan Nur al-Din atau Adid. Ketika khalifah Nur al-Din meninggal, kekhalifahan digantikan oleh Salahuddin Yusuf al-Ayyubi. Dengan pergantian khalifah tersebut, berganti pula kekhalifahannya, dari kekhalifahan Dinasti Fatimiyah menjadi kekhalifahan Dinasti Ayyubiyah. 
Berdirinya kekhalifahan Ayyubiyah disebut juga sebagai periode kedua atau periode orang-orang Syiria. Pada periode ini Salahuddin menjadi penguasa Arab terpenting dan the Champion of Islam (Ibrahim, 1989: 285). Salahuddin berhasil mempersatukan Mesir dan Syria, Mesopotamia, dan Yaman. Salahuddin juga berhasil dalam beberapa perang melawan orang-orang Salib. Pemimpin Dinasti Ayyubiyah secara urut, yaitu Salahuddin Yusuf alAyyubi (1169-1193 M), al-'Aziz (11931198 M), al-Manshur Muhammad (1198-1199 M), al- 'Adil I (1199-1218 M), Al-Kamil (1218-1238 M), Al-'Adil II (1238-1240 M), Al-Shalih Najm alDin/Salih Ayyub (1240-1249 M), Turan Syah (1250), Al-Asyraf Musa (12501252 M). Di antara para Khalifah tersebut, hanya ada empat Khalifah yang terkenal, yaitu Salahuddin Yusuf al-Ayyubi, Al-'Adil I, Al-Kamil, dan Salih Ayyub.

Masa kejayaan Dinasti Ayyubiyah adalah di masa kekhalifahan Salahudin Yusuf al-Ayyubi. Salahuddin adalah pendiri sekaligus khalifah pertama Dinasti Ayyubiyah. Ketika pertama kali ke Mesir dan melihat kepemerintahan di Mesir, ia memiliki dua ambisi besar, yaitu pertama menggantikan Syiah di Mesir dengan Sunni, kedua ia ingin memerangi orang Franka dalam Perang Suci (Armando, 2005: 120). Sebelum pengangkatannya menjadi khalifah oleh Dinasti Abbasiyah, ia telah menjabat sebagai menteri di pemerintahan Dinasti Fatimiyah. Namun setelah khalifah terakhir Dinasti Fatimiyah, yaitu Nur Al-Din wafat, Salahuddin secara pribadi meminta kepada Khalifah Abbasiyah untuk melantiknya sebagai penguasa atas wilayah Mesir, Maroko, Nubia, Arab Barat, Palestina dan Syuriah Tengah (Hitti, 2005: 825).

$$
\text { Salahuddin Yusuf al-Ayyubi }
$$

dianggap sebagai panglima tentara Suriah. Pada awalnya, setelah menduduki jabatan perdana menteri di Mesir, ia diperintahkan Nuruddin Zangi untuk menghilangkan nama Khalifah alAdid dari khotbah Jum'at, yang berarti berakhirnya masa kekuasaan Dinasti Fatimiyah. Meskipun tampak enggan dan berat, akhirnya ia melakukan juga tugas ini. Sebagai gantinya, disebut nama khalifah Abbasiyah dan sejak itu bendera Abbasiyah mulai berkibar di tanah Mesir. Khalifah al-Mustadi kemudian memberinya gelar al-Mu'iz li Amirul Mu'minin. Sebagai imbalannya pada tahun $566 \mathrm{H} / 1175 \mathrm{M}$ khalifah menyerahkan Mesir, an-Naubah, Yaman, Tripoli, Palestina, Suriah bagian Tengah, dan Maghribi (Negara Islam di Afrika Utara) di bawah kekuasaan Salahuddin Yusuf al-Ayyubi. Sejak itulah dia dianggap sebagai Sultanul Islam wal Muslimin (Armando, 2005: 119).

\section{Ekspedisi Napoleon Bonaparte ke Mesir}

Setelah selesainya Revolusi 1789 Prancis mulai menjadi negara besar yang mendapat sainga dan tantangan dari Inggris. Inggris di waktu itu telah meningkat kepentingan-kepentingannya di India dan untuk memutuskan komunikasi antara Inggris di Barat dan India di Timur, Napoleon melihat bahwa Mesir perlu di letakkan di bawah kekuasaan Prancis. Di samping itu Prancis perlu pada pasaran baru untuk hasil perindustriannya. Napoleon sendiri kelihatannya mempunyai tujuan sampingan lain. Aleksander Macedonia pernah menguasai Eropa dan Asia sampai ke India, dan Napoleon ingin mengikuti jejak Aleksander ini. Tempat strategis untuk menguasai kerajaan besar seperti yang dicita-citakannya itu, adalah Kairo dan bukan Roma atau Paris. Inilah beberapa hal yang mendorong Prancis dan Napoleon untuk menduduki Mesir.

Mesir pada waktu itu berada di bawah kekuasaan kaum Mamluk, 
sungguhpun sejak ditaklukkan Sultan Salim di tahun 1517, daerah ini pada hakikatnya merupakan bagian dari kerajaan Usmani (Nasution, 1992: 132). Tetapi setelah bertambah lemahnya kekuasaan sultan-sultan di abad ke-17, Mesir mulai melepaskan diri kekuasaan Istanbul dan akhirnya menjadi daerah otonom. Sultan-sultan Usmani tetap mengirim seorang Pasya Turki ke Kairo untuk bertindak sebagai wakil mereka dalam memerintah daerah ini. Tetapi karena kekuasaan sebenarnya terletak di tangan Kaum Mamluk, kedudukannya di Kairo tidak lebih dari kedudukan seorang duta besar.

Kaum Mamluk berasal dari budakbudak yang dibeli di Kaukasus, suatu daerah pegunungan yang terletak di daerah perbatasan antara Rusia dan Turki. Mereka dibawa ke Istanbul atau ke Kairo untuk diberi didikan militer, dan dalam dinas kemiliteran kedudukan mereka meningkat dan di antaranya ada yang dapat mencapai jabatan militer tertinggi. Setelah jatuhnya prestise sultan-sultan Usmani, mereka tidak mau lagi tunduk kepada Istanbul bahkan menolak pengiriman hasil pajak yang mereka pungut dengan secara kekerasan dari rakyat Mesir ke Istanbul. Kepala mereka disebut Syeikh al-Balad dan syeikh ini yang sebenarnya menjadi raja di Mesir pada waktu itu. Karena mereka bertabiat kasar dan biasanya hanya tahu bahasa Turki dan tak pandai berbahasa Arab, hubungan mereka dengan rakyat Mesir tidak begitu baik (Armando, 2005: 259).

Bagaimana lemahnya pertahanan kerajaan Usmani dan kaum Mamluk di ketika itu, dapat digambarkan dari perjalanan perang di Mesir. Napoleon mendarat di Alexandria pada tanggal 2 juni 1798 dan keesokan harinya kota pelabuhan yang penting ini jatuh. Sembilan hari kemudian, Rasyid, suatu kota yang terletak di sebelah timur Alexandria, jatuh pula. Pada tanggal 21
Juli tentara Napoleon sampai di daerah pyramid di dekat Kairo. Pertempuran terjadi di daerah itu dan kaum Mamluk karena tak sanggup melawan senjatasenjata meriam Napoleon, lari ke Kairo. Tetapi di sini mereka tidak mendapat simpati dan sokongan dari rakyat Mesir. Akhirnya mereka terpaksa lari dari daerah Mesir sebelah selatan. Pada tanggal 22 Juli, tidak sampai tiga minggu setelah mendarat di Alexandria, Napoleon telah dapat menguasai Mesir (Nasution, 1992: 134).

Nasution (1992: 134) menggambarkan ketika Napoleon datang ke Mesir tidak hanya membawa tentara, akan tetapi terdapat 500 orang sipil 500 orang wanita. Diantara jumlah tersebut terdapat 167 orang ahli dalam berbagai cabang ilmu pengetahuan dan membawa 2 unit percetakan dengan huruf Latin, Arab dan Yunani. Tujuannya untuk kepentingan ilmiah yang pada akhirnya dibentuk sebuah lembaga ilmiah dinamai Institut d'Egypte terdiri dari ilmu pasti, ilmu alam, ekonomi politik, dan sastera seni. Lembaga ini boleh dikunjungi terutama oleh para ulama dengan harapan akan menambah pengetahuan tentang Mesir dan mulailah terjadi kontak langsung dengan peradaban Eropa yang baru lagi asing bagi mereka.

$\begin{array}{ccc}\text { Alat percetakan yang } & \text { dibawa } \\ \text { Napoleon } & \text { tersebut } & \text { menjadi } \\ \text { perusahaan } & \text { percetakan } & \text { Balaq, }\end{array}$ perusahaan tersebut berkembang sampai sekarang. Sedangkan peralatan modern pada Institut ini seperti mikroskop, teleskop, atau alat-alat percobaan lainnya serta kesungguhan kerja orang Prancis merupakan hal yang asing dan menakjubkan bagi orang Mesir pada saat itu.

Usaha Napoleon untuk menguasai daerah-daerah lainnya di Timur tidak berhasil dan sementara itu perkembangan politik di Prancis menghendaki kehadirannya di Paris. 
Pada tanggal 18 Agustus 1799, ia meninggalkan Mesir dan kembali ke tanah airnya. Ekspedisi yang dibawanya ia tinggalkan di bawah pimpinan Jenderal Kleber. Dalam pertempuran yang terjadi tahun 1801 dengan armada Inggris, kekuatan Prancis di Mesir mengalami kekalahan. Ekspedisi yang dibawa Napoleon itu meninggalkan Mesir pada tanggal 31 Agustus 1801.

Namun bila dianalisis dari aspek sejarah sosial dapat ditegaskan di sini bahwa walaupun Napoleon menguasai Mesir hanya dalam waktu sekitar tiga tahun, namun pengaruh yang ditinggalkannya sangat besar dalam kehidupan bangsa Mesir. Napoleon Bonaparte menguasai Mesir sejak tahun $1798 \mathrm{M}$, merupakan momentum baru bagi sejarah umat Islam, khususnya di Mesir yang menyebabkan bangkitnya kesadaran akan kelemahan dan keterbelakangan mereka. Kehadiran Napoleon Bonaparte di samping membawa pasukan yang kuat, juga membawa para ilmuwan dengan seperangkat peralatan ilmiah untuk mengadakan penelitian. Keberadaan ini memberi kontak baru bagi tumbuhnya dinamika pengetahuan di kalangan intelektual Muslim untuk menggali ilmu pengetahuan dengan cara-cara yang ilmiah yaitu penelitian.

\section{Latar Belakang Munculnya Modernisasi Pendidikan di Al-Azhar Mesir}

Akibat dari keterbelakangan umat Islam di Mesir, maka hal itu membawa sebuah spririt untuk keluar dan maju sejajar dengan Eropa dan Barat. Modernisasi di al-Azhar bukanlah muncul begitu saja, akan tetapi dilatarbelakangi oleh sejarah sosial di mana terjadinya beberapa hal melingkupinya (Wijaya, 1992: 6). Keberadaan al-Azhar di Mesir bagi penguasa saat itu, sangat krusial untuk melanggengkan kekuasaannya karena dijadikan sebagai simbol bagi penguatan ideologi penguasa.

Setelah mengalami masa kebekuan pemikiran di al-Azhar Mesir, para pemikir Islam berusaha keras untuk membangkitkan Islam kembali, termasuk di dalamnya gagasan pendidikan. Kebangkitan kembali ini timbul sebagai reaksi terhadap sikap taqlid dan jumud, yang ditengarai akibat dari mundurnya aktivitas ijtihad bahkan pintu ijtihad telah tertutup, membawa kemunduran dunia Islam secara keseluruhan. Maka kemudian muncullah gerakan-gerakan baru yang memelopori perubahan mendesak di kalangan umat Islam, sebagai wujud kesadaran dari kebangkitan kembali pendidikan Islam (Armando, 2005: 137). Bagi mayoritas pengamat, sejarah kebangkitan dunia Islam pada umumnya dan pendidikan Islam khususnya, terjadi karena dampak Barat. Mereka memandang Islam sebagai suatu massa yang semi mati yang menerima pukulan-pukulan yang destruktif atau pengaruh-pengaruh yang formatif dari Barat. Terjadinya modernisasi pendidikan yang mendesak dilaksanakan di al-Azhar Mesir saat itu, paling tidak dapat dilihat dari beberapa hal yang melatarbelakangi.

Pertama, bergesernya paham rasional Syi'ah pada ortodoksi ideologi Sunni. Persoalan krusial yang menjadi perhatian tentang sejarah sosial modernisasi di Al-Azhar adalah adanya perpindahan pemikiran dari teologi Syi'ah yang berpaham rasionalis kepada teologi Sunni yang berpaham ortodoks (Armando, 2005: 258-261). Tampaknya persolan penting di sini di mana teologi masing-masing paham dipergunakan untuk menguasai sebuah negara secara keseluruhan. Penguasa yang berkuasa di masa itu selalu memiliki ideologi yang harus diikuti oleh semua masyarakat dan menjadikannya paham resmi negara. 
Dan penguasa berusaha untuk menjaga paham itu dengan memberikan berbagai aturan untuk melanggengkan ideologinya. Pergeseran ini memberikan dampak besar bagi posisi al-Azhar dalam proses perkembangannya termasuk juga bagi kemajuan dunia Islam masa itu. Sebab keberadaan AlAzahar menjadi pusat perebutan kekuasaan sebagai alat untuk menyebarkan ideologi masing-masing penguasa dalam rangka mensukseskan kepemimpinan.

Hal ini tampak jelas, di mana dua paham penguasa besar di Mesir yaitu Dinasti Fatimiyah dan Dinasti Ayyubiyah memiliki ideologi masingmasing yang berbeda dan menjadikannya paham resmi negara yang harus diikuti oleh masyarakat dan sifanya mengikat. Di mana Dinasti Fatimiyah yang berideologi Syi'ah yang lahir dari orang-orang Persia adalah masyarakat memiliki kultur rasionalis. yang sejak dari awalnya memang sudah terbiasa dengan berpikir rasional (Armando, 2005: 313). Maka tidak heran jika Dinasti Fatimiyah sungguh banyak melahirkan tokoh dan pemikirpemikir Islam yang melahirkan ilmu pengetahuan bagi kemajuan Islam, karena tradisi rasional telah mengakar dalam pola berpikir masyarakatnya. Di sini dapat ditegaskan bahwa Dinasti Fatimiyah sangat dekat dan konsen dengan ilmu pengetahuan. Maka alAzhar pun dijadikan sebagai lembaga penting untuk mendidik paham Syi'ahrasionalis pada masyarakat melalui proses pendidikan. Umat Islam pada masa ini mengalami kemajuan pesat dan menguasai ilmu pengetahuan dunia secara universal.

Runtuhnya Dinasti Fatimiah yang bermazhab Syi'ah oleh Dinasti Ayyubiyah yang bermazhab Sunni di Mesir memberi pengaruh besar terhadap pemikiran dan orientasi AlAzhar. Perubahan orientasi al-Azhar terjadi menyusul ambruknya kekhalifahan Fatimiyah di Kairo. Setelah hampir 200 tahun digunakan Bani Fatimiyah sebagai basis pendidikan dan penyebaran doktrindoktrin Syi'ah, al-Azhar diambil alih Salahuddin al-Ayyubi untuk dijadikan madrasah-masjid yang berorientasi Sunni. Berlainan dengan Bani Fatimiyah yang menekankan pengajaran filosofis dan teologis, Dinasti Ayyubiyah, sebagaimana penguasa dan pemuka Sunni yang lain, lebih mementingkan pengajaran fikih dalam madrasah yang mereka kelola, termasuk al-Azhar. Pengambilalihan ini, sebenarnya telah mereduksi posisi al-Azhar yang berorientasi supralokal menjadi lembaga yang berwawasan sempit dikarenakan lingkup politik Dinasti Ayyubiyah yang bercorak lokal.

Akibatnya, umat Islam tergiring pada pemikiran ortodoks yang hanya memikirkan kehidupan akhirat yang bersifat fiqhiyah. Pemikiran rasional, seperti filsafat, tidak boleh lagi berkembang di Al-Azhar karena akan membuat orang menjadi kafir, berganti dengan pemikiran ortodoks yang hanya menerima hidup ini apa adanya yaitu jabariah. Berkembangnya pemikiran Sunni ini, ternyata berdampak bagi tertutupnya pintu ijtihad, yang pada akhirnya membuat ilmu pengetahuan stagnan dan tidak berkembang. Sebuah realita di mana kelak ditengarai hal ini menjadi awal kemunduran pendidikan sekaligus dunia Islam itu secara keseluruhan.

Sejarah membuktikan bahwa kelengahan umat Islam dalam memahami pergeseran "agama yang benar" kepada "ortodoksi ideologi", akibatnya ketika agama telah berubah menjadi dogma-dogma fiqih teologi Asy'ari, umat Islam kehilangan kesempatan menatap sisi-sisi negatif dikotomi itu. Ditambah lagi kehadiran berbagai mazhab yang berseteru, partai 
yang bersaing, kelompok-kelompok muslim yang berselisih dan organisasiorganisasi sosial keagamaan yang tidak akur adalah manifestasi dominasi fiqih yang menggerus akar kekuatan umat.

Di sini dapat dianalisis bahwa karakter ideologi Sunni yang dianut oleh Dinasti Ayyubiyah adalah untuk memperkuat ideologi Islam secara simbolis. Islam yang dianut hanyalah mengedepankan aspek-aspek ritualis yang simbolis dan kurang mengedepankan aspek rasionalitas. Tampaknya ideologi Sunni ini juga adalah untuk memperkuat identitas Islam melalui teologi bahwa Islam tidak sama dengan Barat. Hal penting dari paham ini juga adalah bahwa teologi yang dikembangkan bersifat fikih dan tasawuf, sementara pemikiran rasional yang mengedepankan akal untuk berpikir rasional tidak lagi menjadi budaya.

Akibatnya, pendidikan Islam di AlAzhar mengalami kemunduran yang berdampak juga bagi kemunduran umat Islam. Bekembangnya paham sunni, ternyata berdampak bagi kemunduran ilmu pengetahuan. Kondisi tersebut berlanjut hingga umat Islam merasa antipati terhadap golongan Mu'tazilah, golongan yang gencar menyebarkan ajaran rasionalis. Sejak itu masyarakat tidak mau lagi mendalami ilmu-ilmu sains dan filsafat (Asrohah, 1999: 123). Pemikiran rasional dan ilmiah tidak lagi menjadi budaya berpikir masyarakat Muslim sampai akhirnya pola pikir rasional berubah menjadi cara berpikir tradisional yang dipengaruhi oleh ajaran spiritualitas, tahayyul, dan kejumudan (Asrohah, 1999: 123). Gejala kemunduran pendidikan Islam, menurut Zuhairini mulai tampak setelah abad ke-13 M, yang ditandai dengan terus melemahnya pemikiran umat Islam sampai abad ke-18 M (Zuhairini, 1995: 110).
Antipati terhadap Mu'tazilah juga telah mengakibatkan pengawasan yang ketat terhadap penerapan kurikulum di madrasah. Jatuhnya paham Mu'tazilah talah mengangkat kaum konservatif menjadi kuat. Dalam rangka mengembalikan paham sunni sekaligus memperkokoh basis kemasyarakatan, para ulama sering melakukan kontrol terhadap kurikulum di lembagalembaga pendidikan (Fauzan, 2005: 164). Pada masa ini, materi pelajaran sangat minim, hanya terbatas pada ilmu-ilmu agama, bahkan pendidikan Islam lebih identik dengan pengajaran tasawuf dan fikih. Kondisi demikian terus diperburuk seiring dengan runtuhnya kota Baghdad, akibat serangan tentara Mongol pada tahun $1258 \mathrm{M}$, yang berakibat pada kehancuran kebudayaan dan pusat pendidikan Islam. Hal ini kemudian berdampak pada situasi politik dan membuat lemahnya sektor pendikan, baik institusi, metodologi, bahkan tujuan pendidikan Islam.

Kedua, invasi Napoleon Bonaparte dari Prancis yang mengalahkan Kerajaan Turki Usmani di Mesir dalam waktu yang cepat. Begitu cepatnya Napoleon menguasai Mesir-dalam kurun waktu tiga minggu-menggambarkan betapa lemahnya pertahanan perang yang dimiliki oleh kerajaan Usmani. Pertahanan Kerajaan Usmani dan kaum Mamluk yang lemah pada waktu itu, dapat digambarkan dari perjalanan perang di Mesir. Napoleon mendarat di Alexandria pada tanggal 2 Juni 1798 dan keesokan harinya kota Pelabuhan yang penting ini jatuh. Sembilan hari kemudian, Rasyid, suatu kota yang terletak di sebalah Timur Alexandria, jatuh pula. Pada tanggal 21 Juli tentara Napoleon sampai di daerah Piramid di dekat Kairo. Pertempuran terjadi di tempat itu dan Kaum Mamluk yang tak mampu membendung kekuatan 
Napoleon, lari ke Kairo. Tetapi di sini mereka tidak mendapatkan sokongan dari rakyat Mesir, akhirnya mereka lari lagi ke Mesir sebelah selatan.

Dalam jangka waktu tidak sampai tiga minggu, tepatnya tanggal 22 Juli, Napoleon telah dapat menguasai Mesir. Begitu mudahnya pasukan Napoleon menguasai Mesir yang melukiskan betapa kuatnya pasukan yang dibawa Napoleon dan juga ditambah kekuatan Mesir yang tidak begitu maju jika dibandingkan Perancis. Hal ini memberikan sentakan bagi umat Islam di Mesir, betapa lemahnya kondisi penguasa kala itu. Kondisi ini kemudian menggiring opini masyarakat kala itu untuk bangkit dari keterlenaan panjang akan kekuasaan yang dimiliki, ternyata sudah lemah. Persentuhan ini membawa gerakan dan aksi untuk bangkit dari keterpukuran dan menyadari kelemahan serta berusaha melalui pendidikan, ekonomi, militer dan lainnya.

Ketika Napoleon Bonaparte menginjakkan kakinya di Mesir pada tahun 1798, Mesir berada dalam kondisi yang sangat memprihatinkan. Secara politik, negeri ini terbelah oleh dua kekuatan yang saling menghancurkan, yakni, kekuatan Mamluk yang berkuasa secara turuntemurun sejak abad ke-13 dan kekuatan yang didukung oleh pemerintahan Utsmani di Istanbul (Nasution, 1992: 59).

Situasi kekuasaan dan pemerintahan di Mesir pada waktu itu sudah tidak dapat lagi dikatakan stabil. Kekacauan, kemerosotan sosial kemasyarakatan sebagai wilayah yang selalu diperebutkan dan diincar oleh negara-negara Islam kuat sungguhsungguh membuat rakyat Mesir diliputi rasa ketakutan. Perhatian untuk membangun pun sangat lemah, sebab setiap saat selalu dihantui oleh perang. Dengan keadaan sedemikian lemah posisi Mesir, datanglah tentara Napoleon yang melebarkan sayap imperialnya ke wilayah-wilayah lain yang mempunyai potensi kekayaan alam, peradaban dan warisan-warisan historis yang memungkinkan untuk dijadikan batu pijakan bagi kejayaan mereka dalam membangun impian menguasai dunia (Nasution, 1992: 59).

Mesir adalah sebuah negara yang masyarakatnya memiliki nilai religius tinggi. Mereka memandang agama di atas segala-galanya, sebagai bagian integral dari budaya, adat istiadat, dan masyarakat itu sendiri. Kelompokkelompok Islam selalu bersikukuh untuk tidak terpengaruh dengan Barat. Karena menurut mereka Islam sebenarnya lebih unggul dibanding orang-orang Barat. Mereka mengidealisasikan periode awal Islam dan menurut ajaran mereka hanya kembali ke zaman keemasan inilah Mesir modern bisa sembuh dari segala penyakit. Dengan berdalih bahwa pengaruh Barat yang dimulai dari invasi Napoleon sebagai akar segala kebobrokan, mereka mendukung tulisan-tulisan dan deklarasi-deklarasi mereka dengan tafsir Al-Qur'an dari Ibnu Hanbal dan Ibnu Taimiyah yang keduanya menyeru untuk membaca AlQur'an secara tekstual, sembari menolak semua penafsiran, filsafat, dan teks-teks yang menyertai.

Ketiga, persentuhan peradaban Prancis yang dibawa Napoleon pada pendidikan di Al-Azhar. Pembaharuan dan modernisasi pendidikan di Mesir berawal dari datangnya Napoleon Bonaparte di Alexandria, Mesir pada tanggal 2 Juli $1798 \mathrm{M}$. Tujuan utamanya adalah menguasai daerah Timur, terutama India. Napolen Bonaparte menjadikan Mesir, hanya sebagai batu loncatan saja untuk menguasai India, yang pada waktu itu dibawah pengaruh kekuasaan kolonial Inggris. Kedatangan Napolen ke Mesir tidak hanya dengan 
pasukan perang, tetapi juga dengan membawa seratus enam puluh orang diantaranya pakar ilmu pengetahuan, dua set percetakan dengan huruf latin, Arab, Yunani, peralatan eksperimen (seperti: teleskop, mikroskop, kamera, dan lain sebagainya), serta seribu orang sipil. Tidak hanya itu, ia pun mendirikan lembaga riset bernama Institut di Egypte, pembangunan yang mengenalkan ilmu pengetahuan modern terhadap Mesir dan mengenalkan sejarah Mesir pada Eropa modern melalui karya yang mereka tulis. Ilmu-ilmu yang terdiri dari empat element, yaitu: ilmu alam, ilmu pasti, ekonomi dan politik, serta ilmu sastra dan kesenian. Lembaga ini bertugas memberikan masukan bagi Napoleon dalam memerintah Mesir. Lembaga ini terbuka untuk umum terutama ilmuwan (ulama) Islam.

Walaupun Napoleon menguasai Mesir hanya dalam waktu sekitar tiga tahun, namun pengaruh yang ditinggalkannya sangat besar dalam kehidupan bangsa Mesir. Napoleon Bonaparte menguasai Mesir sejak tahun 1798 M. Ini merupakan momentum baru bagi sejarah umat Islam, khususnya di Mesir yang menyebabkan bangkitnya kesadaran akan kelemahan dan keterbelakangan mereka. Kehadiran Napoleon Bonaparte di samping membawa pasukan yang kuat, juga membawa para ilmuwan dengan seperangkat peralatan ilmiah untuk mengadakan penelitian (Mubarok, 2008: 227).

Ini adalah momen pertama kali ilmuwan Islam kontak langsung dengan peradaban Eropa, termasuk Abd alRahman al-Jabarti. Baginya perpustakaan yang dibangun oleh Napoleon sangat menakjubkan karena Islam diungkapkan dalam berbagai bahasa dunia. Untuk memenuhi kebutuhan ekspedisinya, Napoleon berusaha keras mengenalkan teknologi dan pemikiran modern kepada Mesir serta menggali Sumber Daya Manusia (SDM) Mesir dengan cara mengalihkan budaya tinggi Perancis kepada masyarakat setempat. Sehingga dalam waktu yang tidak lama, banyak diantara cendekiawan Mesir belajar tentang perpajakan, pertanian, kesehatan, administrasi, dan arkeologi.

Institut d'Egypte boleh dikunjungi orang Mesir, terutama para ulamanya, yang diharapkan oleh ilmuwanilmuwan Praancis yang bekerja di lembaga itu, akan menambah pengetahuan mereka tentang Mesir, adat istiadatnya, bahasa dan agamanya. Di sinilah orang-orang Mesir dan umat Islam buat pertama kali mempunyai kontak langsung dengan peradaban Eropa yang baru lagi asing bagi mereka itu.

Abd al-Rahman al-Jabarti, seorang ulama dari al-Azhar dan penulis sejarah, pernah mengunjungi lembaga itu di tahun 1799. Hal menarik yang menjadi perhatiannya ialah perpustakaan besar yang mengandung buku-buku, bukan hanya dalam bahasa Arab, Persia dan Turki. Di antara ahli-ahli yang dibawa Napoleon memang terdapat kamum orientalis yang pandai dan mahir berbahasa Arab. Merekalah yang menerjemahkan perintah dan maklumat-maklumat Napoleon ke dalam bahasa Arab.

Demikianlah kesan seorang cendikiawan Islam waktu itu terhadap kemajuan kebudayaan Barat. Ini menggambarkan betapa mundurnya umat Islam ketika itu. Keadaan menjadi berbalik 180 derajat. Kalau di Periode Klasik orang Barat yang kagum melihat kebudayaan dan peradaban Islam, di Periode Modern kaum Islam yang heran melihat kebudayaan dan kemajuan Barat. Di samping kemajuan materi ini, menurut Jaih Mubarak, Napoleon juga membawa ide-ide baru yang dihasillkan Revolusi Prancis, yaitu: 
Pertama, sistem pemerintahan republik yang di dalamnya kepala negara adi pilih untuk waktu tertentu, tunduk kepada Undang-undang Dasar dan bisa dijatuhkan oleh parlemen. Sistem ini berlain sama sekali dengan sistem pemerintahan absolut raja-raja Islam, yang tetap menjadi raja selama ia masih hidup dan kemudian digantikan oleh anaknya, tidak tunduk kepada konstitusi atau parlemen, karena konstitusi dan parlemen memang tidak ada dalam sistem kerajaan itu. Ide yang terkandung dalam kata republik masih sulit ditangkap, dan dengan demikian mencari terjemahannya ke dalam bahasa Arab sulit pula. Dalam maklumat-maklumat Napoleon, Republik Prancis diterjemahkan menjadi Al-Jumhur al-Faransawi. Jumhur sebenarnya berarti orang banyak. Jadi yang tertangkap dari kata republik ialah publik, orang banyak. Di permulaan abad ke-20 inilah kelihatannya baru muncul terjemahan yang lebih tepat, yaitu jumhuriah.

Kedua, ide persamaan (egaliter) dalam arti samanya kedudukan dan turut sertanya rakyat dalam soal pemerintahan. Kalau sebelum ini, rakyat Mesir tak turut serta dalam pemerintahan negara mereka, Napoleon mendirikan suatu badan kenegaraan yang terdiri dari ulama-ulama Al-Azhar dan pemuka-pemuka dalam dunia dagang dari Kairo ke daerah-daerah. Tugas badan ini ialah membuat undangundang, memelihara ketertiban umum dan menjadi pengantara antara penguasa-penguasa Prancis dan rakyat Mesir. Di samping itu didirikan pula suatu badan bernama Diwan al-Ummah yang dalam waktu-waktu tertentu mengadakan sidang untuk membicarakan hal-hal bersangkutan dengan kepentingan nasional. Tiap-tiap daerah mengirimkan Sembilan wakil ke Sidang Diwan itu, tiga dari golongan ulama, tiga dari golongan pedagang, dan satu dari masing-masing golongan petani, kepala desa dan kepala suku bangsa Arab. Diwan ini mempunyai 180 anggota dan sidang pertama diadakan dari tanggal 5 sampai 20 Oktober 1798. Putusan yang diambil ialah menganjurkan perubahan peraturan pajak yang ditetapkan Kerajaan Usmani. Sistem pemilihan ketua lembaga juga merupakan hal baru bagi rakyat Mesir. Ketika dari para anggota Diwan diminta memilih ketua, anggota-anggota menunjuk dan menyebut nama ulama yang mereka hormati, yaitu Syaikh AlSyarqawi. Penunjukan serupa ini ditolak oleh penguasa Prancis sambil menjelaskan cara pengadaan pemilihan.

Ketiga, ide kebangsaan yang terkandung dalam maklumat Napoleon bahwa orang Prancis merupakan suatu bangsa (nation) dan bahwa kaum Mamluk adalah orang asing dan datang ke Mesir dari Kaukasus. Jadi, sungguhpun orang Islam tetapi berlainan bangsa dengan orang Mesir. Juga maklumat itu mengandung katakata umat Mesir. Bagi orang Islam di waktu itu yang ada hanyalah umat Islam, dan tiap orang Islam itu adalah saudaranya dan ia tak begitu sadar akan perbedaan suku dan bangsa. Hal yang disadarinya ialah perbedaan agama. Oleh karena itu untuk menerjemahkan kata nation ke dalam bahasa Arab juga sulit. Kata Arab yang dipakai ialah millah, umpamanya dalam al-Millah alFaransiah untuk itu adalah la nation Francaise. Millah berarti agama. Kata Arab yang kemudian dipakai untuk nation ialah qaum, sya'b, dan ummah.

Ekspedisi Napoleon tersebut membawa perubahan signifikan bagi perkembangan bangsa Mesir, terutama yang menyangkut pembaharuan dan modernisasi pendidikan Islam di sana (Stanton, 1998: 254). Kemajuan ilmu pengetahuan dan teknologi Perancis banyak memberikan inspirasi bagi tokoh-tokoh Mesir untuk melakukan 
perubahan secara mendasar, pola sistem dan kurikulum pendidikan yang sebelumnya dilakukan secara konvesional. Namun, efek pembaharuan pada al-Azhar baru dirasakan dalam lapangan reorganisasi, sistem ujian, dan pengenalan pokok-pokok kajian baru, dan tidak dalam kandungan ilmu-ilmu Islam seperti teologi dan filsafat. Sebagai contoh di Mesir terdapat tokoh semacam Rifa'ah al-Tahtawi, Muhammad Abduh dalam posisi sebagai anggota Majelis Tinggi Al-Azhar pernah menggagas pembaharuan Al-Azhar dengan memasukkan mata kuliah matematika, aljabar, ilmu ukur dan ilmu bumi ke dalam kurikulum.

\section{Tokoh dan Ide Pembaruan serta Pengaruhnya terhadap Kemajuan Pendidikan di Al-Azhar Mesir}

Akibat dari berbagai hal yang membuat Mesir mengalami pergeseran kekuasaan yang berdampak pada kemunduran umat, maka dibutuhkan adanya perubahan signifikan pada masyarakat. Setelah mengalami masa kebekuan pemikiran selama beberapa abad, para pemikir Islam di Mesir berusaha keras untuk membangkitkan Islam kembali melalui pendidikan. Kebangkitan kembali ini timbul sebagai reaksi terhadap sikap taqlid dan jumud, yang ditengarai akibat dari mundurnya aktivitas ijtihad bahkan pintu ijtihad telah tertutup (Armando, 2005: 137), membawa kemunduran dunia Islam secara keseluruhan. Maka kemudian muncullah gerakan-gerakan baru yang memelopori perubahan mendesak di kalangan umat Islam, sebagai wujud kesadaran dari kebangkitan kembali pendidikan Islam. Bagi mayoritas pengamat, sejarah kebangkitan dunia Islam pada umumnya dan pendidikan Islam khususnya, terjadi karena dampak Barat. Mereka memandang Islam sebagai suatu massa yang semi mati yang menerima pukulan-pukulan yang destruktif atau pengaruhpengaruh yang formatif dari Barat. Periode kebangkitan ini berlangsung mulai sejak abad ke 19, yang merupakan kebangkitan kembali umat Islam, terhadap periode sebelumnya yang dinamakan dengan fase pembaruan (Madjid, 1997: 172-173).

Dapat digambarkan bahwa tokoh pembaru kala itu menginginkan sebuah kebangkitan di kalangan umat Islam terutama di al-Azhar dan Mesir karena telah lama mengalami kebekuan dan kemunduran dibanding Eropa dan Barat. Umat Islam harus bangkit kembali dan itu dimulai dari pengelolaan sistem pendidikan di alAzhar Mesir. Kebangkitan Islam merupakan upaya aktif untuk membangun keseluruhan tatanan sosial sesuai dengan visi ideoligis yang diilhami secara kanonik mengenai realitas. Dengan kata lain, menurut Kuntowijoyo, kebangkitan Islam bukan hanya sekedar reaksi lain terhadap modernisasi, akan tetapi ia merupakan upaya untuk penegasan diri dan aktualisasi terhadap suatu keyakinan universal di dunia temporal.

Secara sosial historis, karakteristik kebangkitan peradaban yang dilakukan oleh para tokoh pembaru di al-Azhar bagi penguatan dan kemajuan Mesir sebagai sebuah negara mengarah pada tiga hal, yaitu proses mengeluarkan umat Islam dari fatalisme dan fanatisme, ideologi dan aksi, dan ideologi ilmu pengetahuan dan aplikasi (Yatim, 2006: 1). Gerakan fatalisme dan fanatisme adalah mengeluarkan umat Islam dari sikap jumud dan fanatik mazhab kepada sikap ijtihad dan berpikir rasional. Gerakan ideologi dan aksi adalah adanya usaha dan keinginan untuk melawan penjajah dengan melakukan aksi dan perlawanan sehingga umat Islam dapat berdiri sendiri untuk maju. Gerakan ideologi 
ilmu pengetahuan dan aplikasi adalah adanya pengembangan ilmu pengetahuan yang dilakukan oleh masyarakat Islam yang diaplikasikan melalui lembaga pendidikan. Para tokoh pembaru berusaha mengeluarkan umat Islam dari sikap fatalisme yang Katiga hal ini menyatu dalam usaha para tokoh pembaru di al-Azhar Mesir.

Berikut ini akan diketengahkan sejarah sosial tiga tokoh pembaru di alAzhar dengan masing-masng idenya serta pengaruhnya bagi kemajuan alAzhar di Mesir dan umat Islam secara keseluruhan. Keempat tokoh itu memiliki karakteristik yang berbeda, tapi memiliki keinginan yang sama untuk kemajuan al-Azhar dan Mesir serta umat Islam. Mereka adalah Muhammad Ali Pasya, Muhammad Abduh, dan Muhammad Rasyid Ridha.

\section{Muhammad Ali Pasya Memasukkan Corak dan Model Pendidikan Barat di Al-Azhar}

Sama halnya di Turki, pembaruan pendidikan Islam selanjutnya dapat dilihat di Mesir yang juga diawali oleh penguasa pembaharuan Islam setelah mengadakan kontak dengan peradaban modern Barat. Invasi Napoleon yang membawa kemajuan teknologi dan ilmu pengetahuan Barat telah membuka mata rakyat Mesir bahwa umat Islam telah tertinggal oleh kemajuan Barat, selanjutnya mendorong umat Islam untuk mengadakan modernisasi yang dipelopori oleh Muhammad Ali Pasya(Armando, 2005: 150). Muhammad Ali Pasya disebut sebagai pelopor pembaruan dan Bapak Pembangunan Mesir Modern. Ia sangat menyadari bahwa pembagunan dunia pendidikan sangat penting artinya bagi kemajuan Mesir sebagai suatu bangsa yang beradab.

Setelah ia naik tahta menjadi penguasa Mesir, ia mengerahkan usaha untuk memperkuat kekuasaannya dan mengadakan pembaruan termasuk di al-Azhar. Pembaruan pertama dilakukannya di bidang militer, karena dengan kekuatan militer ia dapat mempertahankan kekuasaannya. Akan tetapi, kemajuan dalam bidang militer tidak akan mungkin dicapai tanpa dukungan ilmu pengetahuan dan teknologi modern yang berkembang. Untuk mendukung pembiayaan pembaruan angkatan bersenjata, pembaruan di bidang ekonomi juga mendapat perhatiannya yang serius dan untuk itu juga diperlukan ilmu pengetahuan modern (Armando, 2005: 151). Di sini tergambar bahwa kedua pembangunan bidang militer dan ekonomi yang dilakukan Muhammad Ali Pasya sangat membutuhkan ilmu pengetahuan modern dan ini menjadi cikal munculnya pembaruan atau modernisasi di bidang pendidikan (Armando, 2005: 39).

Muhammad Ali Pasya sangat menyadari pentingnya arti pendidikan dan ilmu pengetahuan bagi kemajuan suatu bangsa. Maka, Muhammad Ali Pasya mencurahkan perhatiannya bagi pendidikan termasuk di al-Azhar. Namun, dalam proses perjalannya, alAzhar sebagai lembaga yang memiliki otonomi karena didiami oleh banyak ulama dan seolah-olah milik ulama, menolak modernisasi yang lakukan oleh Muhammad Ali Pasya. Maka, selanjutnya untuk memuluskan ide-ide kebangkitan pembaruannya, dia mendirikan sekolah-sekolah baru. Maka untuk itu, ia mendirikan Kementerian Pendidikan dan Lembaga Pendidikan. Tahun 1815 ia mendirikan Sekolah Militer di Kairo dan Akademi Industri Bahari serta Sekolah Perwira Angkatan Laut di Iskandariyah. Itu semua dimaksudkan untuk membekali anggota angkatan bersenjata dengan ilmu pengetahuan modern (Armando, 2005: 151). Secara berturut-turut ia membuka Sekolah Teknik (1816), Sekolah 
Kedokteran (1827), Sekolah Apoteker (1829), Sekolah Pertambangan (1839), Sekolah Pertanian (1836), dan Sekolah Penerjemahan (1836) (Asrohah, 1999: 133). Di sekolah-sekolah tersebut digunakan metode modern dengan guru yang didatangkan dari Eropa, di samping tenaga dari Mesir sendiri.

Untuk mempercepat pembaruan dalam bidang pendidikan, penerjamahan buku Eropa digalakkan, terutama setelah berdirinya sekolah penerjemahan. Usaha penerjemahan ini mulai membawa hasil baik. Bagian penerjemahan dibagi empat; ilmu pasti, ilmu kedokteran, ilmu fisika dan sastra. Kegiatan tersebut, terutama sastra, membawa masuknya ide-ide Barat ke Mesir. Mereka mulai mengenal Eropa dan semakin menyadari bahwa dunia yang digambarkan buku terjemahan itu sudah jauh berbeda dari buku klasik yang sudah mereka ketahui (Armando, 2005: 151).

Namun demikian, dengan kegigihan Muhammad Ali Pasya, dia berusaha memasukkan pembaruan di al-Azhar. Di sini tergambar bahwa corak dan model pendidikan Barat yang diterapkan oleh Muhammad Ali Pasya Mesir termasuk di al-Azhar dianggap jalan keluar untuk kemajuan umat Muslim Mesir. Khusus untuk al-Azhar, dia memberikan kelonggaran dalam pengawasan terhadap ide pembaruannya. Bagi sekolah-sekolah yang didirikannya, untuk mendukung percepatan pembaruannya ia mempercayakan pengawasan sekolah kepada orang Barat, bahkan gurugurunya juga didatangkan dari Barat (Eropa). Selain mendatangkan tenaga ahli dari Eropa, Muhammad Ali Pasya juga mengirimkan siswa-siswa untuk belajar ke Italia, Perancis, Inggris, dan Austria. Menurut statistik, antara tahun 1823 dan 1844, sekitar 311 orang pelajar Mesir dikirim ke Eropa (Hitti, 2005: 724).
Berbagai terobosan pembaruan dan modernisasi yang dipelopori oleh Muhamad Ali Pasya di Mesir ini besar sekali kontribusinya bagi perkembangan Mesir untuk menjadi negara Modern. Gerakan pembaruannya telah memperkenalkan ilmu pengetahuan dan teknologi Barat kepada umat Islam. Sampai pada suatu waktu dapat menyingkap awan hitam yang menyelimuti pola pikir dan sikap keagamaan sehingga lahirlah intelegensia Muslim yang berpengetahuan agama yang luas, berwawasan modern, dan tidak berpandangan sempit. Mereka laksana mercusuar bagi umat Islam Mesir juga dunia Islam lainnya, karena sinarnya yang mampu memberikan petunjuk umat Islam mendarat di pelabuhan yang menjanjikan kemajuan dan tidak menyesatkan. Mereka seperti Rifa'ah Badawi, Rafi' al-Tahtawi, Muhammad Abduh, Rasyid Rida, dan Hasan alBanna, yang berpikiran luas, berwawasan modern, dan tidak berpandangan ekslusif.

Memang Muhammad Ali Pasya telah melakukan pembaruan secara universal di Mesir melalui pendirian sekolah baru yang mengakomodir pemikiran ilmu pengetahuan Prancis. Namun ide pembaruan yang dibawanya tidak diterima di lembaga pendidikan al-Azhar. Para ulama yang ada di alAzhar agak berat menerima ide rasional yang dibawa Muhammad Ali Pasya karena mereka menganggap bertentangan dengan ideologi mereka yang berpaham Sunni. Dampak yang begitu besar akan ideologi Sunni yang dikembangkan oleh Dinasti Ayyubiyah telah mendarah daging dalam diri masyarakat Mesir. Ideologi Sunni merupakan identitas Islam yang harus dipertahankan dan itu bertetangan dan tidak sama dengan pendidikan Barat. Teologi mereka hanya bersifat fikih dan tasawuf dan sangat bertentangan 
dengan model Barat, sehingga semua model Barat itu harus ditolak.

\section{Muhammad Abduh Memasukkan Ilmu Modern di Al-Azhar}

Upaya pembaruan pendidikan yang telah dilakukan oleh Muhammad Ali Pasya, satu sisi memberikan kontribusi positif bagi lahirnya suasana pendidikan Islam yang dinamis. Bahkan dari adanya pembaruan ini telah lahir pula intelektual Muslim yang berwawasan luas baik pengetahuan agama maupun pengetahuan umum. Namun pada sisi lain, dengan adanya pembaruan pendidikan Islam telah membawa kondisi pendidikan Islamdalam hal ini madrasah-hanya bisa mengajarkan ilmu-ilmu keislaman. Akibatnya lulusan madrasah hanya paham akan ilmu keislaman saja, dan hal ini berdampak pada pola pikir masyarakat yang sempit. Di sini tampak muncul dualisme pendidikan dan pengaruhnya pun terasa besar dalam sistem pendidikan serta juga masyakarat Muslim. Munculnya dualisme pendidikan pada masa ini, betul-betul telah menjadi kenyataan yang memang perlu penanganan serius.

Sosok Muhammad Abduh adalah satu dari sekian banyak pembaru yang merasakan adanya dualisme tersebut (Armando, 2005: 12). Hal itu, apabila dibiarkan akan membawa keberadaan pendidikan Islam pada satu situasi tidak mendapat respon dan diminati oleh masyarakat serta tidak bisa melahirkan para lulusan yang handal. Oleh karenanya, dalam merespon kondisi demikian, Muhammad Abduh mencoba melakukan upaya pembaruan pendidikan di al-Azhar (Nata, 2004: 9198). Menurut pandangannya, al-Azhar perlu dimasukkan ilmu-ilmu modern agar ulama-ulama Islam mengerti kebudayaan modern dan dengan demikian dapat mencari penyelesaian yang baik bagi persoalan dalam zaman modern (Nasution, 1992: 67). Dengan memasukkan ilmu pengetahuan modern di al-Azhar sebagai lembaga pendidikan pemerintah, akan melahirkan ilmuwan yang tidak kosong akan ilmu pengetahuan agama tapi juga menguasai ilmu pengetahuan umum yang dapat memberikan kontribusi bagi pengembangan ilmu pengetahuan dan kamajuan Islam.

Bagi Muhammad Abduh, isu penting yang harus menjadi perhatian sepanjang hayat dan karirnya adalah pembaruan pendidikan Islam. Dalam pandangannya, pendidikan itu penting sekali, sedangkan ilmu pengetahuan itu wajib dipelajari. Sesuatu yang selalu Abduh pikirkan adalah bagaimana mencari alternatif untuk keluar dari stagnasi yang dihadapi sekolah agama di Mesir, yakni pendidikan al-Azhar. Abduh berpendapat bahwa pendidikan yang diamatinya cenderung menghasilkan lulusan dan masyarakat yang jumud, tidak transparan, statis, dan tidak ada perubahan. Oleh karena paham jumud ini, maka umat Islam tidak menghendaki perubahan, dan tidak mau menerima perubahan. Hanya dengan meningkatkan mutu pendidikan Islam dan mengemukakan kembali ajaran-ajaran dasar Islam dengan bahasa yang tegas dan jelas, umat Islam akan mengakhiri kemunduran dan akan menatap kemajuan masa depan (Gibb, 1992: 69).

Bagi Muhammad Abduh yang harus diperjuangkan dalam satu sistem pendidikan adalah pendidikan yang fungsional, yang meliputi pendidikan universal bagi semua anak, laki-laki maupun perempuan. Semuanya harus punya dasar membaca, menulis, berhitung, dan harus mendapatkan pendidikan agama. Isi dan lama pendidikan haruslah beragam, sesuai dengan tujuan dan profesi yang dikehendaki oleh pelajar (Rahmena, 1996: 59). Muhammad Abduh percaya 
bahwa anak petani dan tukang harus mendapat pendidikan yang umum, agar mereka dapat berhasil menjadi ilmuwan masa depan.

Berikutnya, Muhammad Abduh berusaha mendirikan Komite Perbaikan Administrasi al-Azhar pada tahun 1895 dan berhasil melaksanakan pembaruanpembaruan administratif yang bermanfaat. Namun usahanya menghadapi perlawanan dari para ulama bahkan ia dituduh akan menghidupkan kembali pemikiranpemikiran Mu'tazilah. Dalam rangka mengubah sistem pendidikan tersebut, Muhammad Abduh mempunyai ide yang tidak bisa direalisir hanya karena benturan dari kelompok konservatif yang belum memahami betul manfaat dari adanya pembaruan. Oleh sebab itu, ia merintis pendirian lembaga pendidikan Majlis Pengajaran Tinggi yang bisa mengajarkan ilmu agama dan ilmu umum sekaligus pada lembagalembaga pendidikan Islam (Suwito \& Fauzan, 2005: 175).

Selain itu, pembaruan pendidikan Islam yang dilakukannya adalah menyebarkan secara luas ide-ide pembaruannya ke seluruh wilayah termasuk kepada para guru dan civitas akademika al-Azhar. Usaha tersebut membuahkan hasil dengan munculnya sedikit demi sedikit para pemimpin alAzhar bergerak dan terdorong untuk menata kembali metode-metode mengajar, serta mengajarkan sejarah, geografi, dan beberapa cabang ilmu lainnya tentang alam. Dengan demikian upaya pembaruan yang ditujukan ke alAzhar meliputi; (1) membentuk Dewan Pimpinan al-Azhar yang terdiri dari ulama-ulama besar dari empat mazhab; (2) menertibkan administrasi al-Azhar dengan menentukan honor bagi pengajar, membangun ruang khusus bagi rektor, dan mengangkat para pembantu rektor; dan (3) masa belajar diperpanjang dan masa libur diperpendek (Armando, 2005: 14).

\section{Muhammad Rasyid Ridha Memasukkan Pemikiran Rasional di al-Azhar}

Ide pembaruan di al-Azhar Mesir yang dilakukan oleh Muhammad Abduh kemudian diteruskan oleh Rasyid Ridha (Nasution, 1992: 69). Pada tahun 1898 Rasyid Ridha hijrah ke Kairo dengan maksud berguru dan bergabung dengan Muhammad Abduh. Langkah pertama yang dilakukan Rasyid di Mesir adalah mendesak Abduh untuk menerbitkan sebuah majalah sebagai corong mereka. Menurut Rasyid, hal ini penting karena cara yang tepat untuk menyembuhkan penyakit umat ialah pendidikan serta menyiarkan ide-ide yang pantas untuk menentang kebodohan dan pikiranpikiran yang mengendap dalam diri umat seperti fatalistik dan khurafat. Abduh menyetujui saran muridnya itu, kemudian terbitlah sebuah majalah yang diberi nama al-Manar. Nama yang diusulkan Rasyid dan disetujui Abduh. Dalam terbitan perdananya dijelaskan bahwa tujuan al-Manar sama dengan al'Urwah al-Wusqa, yakni sebagai media pembaharuan dalam bidang agama, sosial, ekonomi, menghilangkan pahampaham yang menyimpang dari agama Islam, peningkatan mutu pendidikan, dan membela umat Islam dari kebuasan politik Barat (Ilahi, 2002: 58).

Erat kaitannya dengan konsep "jihad" yang dikemukakannya, Rasyid menganjurkan umat Islam memiliki satu kekuatan untuk menghadapi beratnya tantangan dunia modern. Kekuatan itu hanya dapat dimiliki jika umat Islam bersedia menerima peradaban Barat. Jalan untuk memperoleh peradaban Barat itu ialah berusaha memperoleh ilmu pengetahuan dan teknologi Barat itu sendiri. Ilmu pengetahuan dan teknologi tidak berlawanan dengan Islam (Nasution, 1992: 71), bahkan 
umat Islam wajib mempelajari dan menerima ilmu pengetahuan dan teknologi itu bila mereka ingin maju (Ilahi, 2002: 64).

Secara umum terdapat empat pemikiran penting Rasyid Ridha yang harus dilakukan oleh umat Islam agar keluar dari keterkungkungan keterbelakangan dan kemunduran. Semua itu harus dimulai dari lembaga pendidikan al-Azhar, yaitu:

Pertama, menyingkarkan paham bid'ah dan paham fatalisme umat Islam. Hampir tidak jauh berbeda pemikiran Rasyid Ridha mengenai pembaruannya dengan para gurunya, yaitu Muhammad 'Abduh dan Jamaluddin al-Afghani. Ia juga berpendapat bahwa umat Islam mundur karena tidak menganut ajaranajaran Islam yang sebenarnya. Pemahaman umat Islam tentang ajaranajaran agama mengalami kesalahan dan perbuatan-perbuatan mereka dianggap telah menyeleweng dari ajaran Islam yang hakiki. Ke dalam tubuh Islam telah banyak masuk bid'ah yang merugikan bagi perkembangan dan kemajuan umat. Maka Rasyid Rida berusaha merubah paham masyarakat dan pola pembelajaran di al-Azhar dengan menyingkirkan paham fatalisme di kalangan mahasiswa dan dosen. Pemikiran ini jelas mengarahkan umat Islam agar berpikir rasional dan mengedepankan akal untuk memberi solusi terhadap persoalan umat (Rais, 1993: 93-94).

Menurut Rasyid Ridha, di antara bid'ah-bid'ah itu ialah pendapat bahwa dalam Islam terdapat ajaran kekuatan batin yang membuat pemiliknya dapat memperoleh segala apa yang dikehendakinya. Bid'ah lain yang ditentang keras oleh Rasyid Ridha ialah ajaran syekh-syekh tarekat tentang tidak pentignya hidup duniawi, tentang tawakkal, dan tentang pujaan dan kepatuhan berlebih-lebihan pada syekh dan wali. Rasyid Ridha menyoroti paham fatalisme (jabari) yang berakar kuat di tengah masyarakat yang telah memperlemah ummat Islam. Kemudian ia menggantikannya dengan paham dinamisme (progress, kemajuan) supaya ummat Islam menyadari bahwa kemajuan hidup ditentukan oleh diri mereka sendiri. Jalan untuk dinamika aktif itu yakni melalui jihad.

Umat Islam, demikian menurut Rasyid Ridha, harus dibawa kembali kepada ajaran Islam yang sebenarnya, murni dari segala bid'ah. Islam murni itu sederhana sekali, sederhana dalam ibadat dan sederhana dalam muamalatnya. Hal yang meruwetkan ajaran Islam adalah justru sunah-sunah yang ditambahkan hingga mengkaburkan antara wajib dan sunnah. Dalam soal muamalah, hanya dasar-dasar yang diberikan, seperti keadilan, persamaan, pemerintahan syura. Perincian dan pelaksanaan dari dasar-dasar ini diserahkan kepada umat untuk menentukannya. Hukum-hukum fiqh mengenai hidup kemasyarakatan, tidak boleh dianggap absolut dan tak dapat diubah. Hukum-hukum itu timbul sesuai dengan suasana tempat dan zamannya.

Terhadap sikap fanatik di zamannya ia menganjurkan supaya toleransi bermazhab dihidupkan. Dalam hal-hal fundamentallah yang perlu dipertahankan, yaitu persatuan umat. Selanjutnya ia menganjurkan pembaruan dalam bidang hukum dan penyatuan mazhab hukum. Rasyid Ridha mengakui terdapat faham fatalisme di kalangan umat Islam. Menurutnya, bahwa salah satu dari sebab-sebab yang membawa kepada kemunduran umat Islam ialah faham fatalisme ('aqidah al-jabr) itu. Selanjutnya salah satu sebab yang membawa masyarakat Eropa kepada kemajuan ialah faham dinamis yang terdapat di kalangan mereka. Islam 
sebenarnya mengandung ajaran dinamis. Orang Islam disuruh bersikap aktif. Dinamis dan sikap aktif itu terkandung dalam kata jihad; jihad dalam arti berusaha keras, dan sedia memberi pengorbanan, harta bahkan juga jiwa. Faham jihad inilah yang menyebabkan umat Islam di zaman klasik dapat menguasai dunia.

\section{Kedua,}

mengembangkan

pemikiran ijtihad. Sebagaimana Muhammad 'Abduh, Rasyid Ridha sangat menghargai akal manusia, walaupun penghargaannya terhadap akal tidak setinggi penghargaan yang diberikan gurunya. Akal dapat dipakai dalam menafsirkan ajaran-ajaran mengenai hidup kemasyarakatan, tetapi tidak terhadap ibadah. Ijtihad dalam soal ibadah tidak lagi diperlukan. Ijtihad (fungsi eksplorasi akal) dapat dipergunakan terhadap ayat dan hadis yang tidak mengandung arti tegas dan terhadap persoalan-persoalan yang tidak disebutkan secara langsung dalam al-Qur'an dan al-Hadits. Di sinilah, menurut Rasyid Ridha, terletak dinamika Islam. Rasyid Ridha menyoroti paham fatalisme (jabariah) yang berakar kuat di tengah masyarakat yang telah memperlemah umat Islam. Kemudian ia menggantikannya dengan paham dinamisme (progress, kemajuan) supaya umat Islam menyadari bahwa kemajuan hidup ditentukan oleh diri mereka sendiri (Armando, 2005: 44). Jalan untuk dinamika aktif itu yakni melalui jihad (Armando, 2005: 44).

Rasyid Ridha banyak menyoroti masalah akidah Islam yang hubungannya dengan praktik di tengah masyarakat.dan berusaha memberantas taqlid di kalangan umat Islam. Paham yang dimunculkan Rasyid Ridha tidak jauh berrbeda dengan Abduh yang berusaha mengembalikan sifat khas ajaran salaf kepada keasliannya. Oleh karena itu Rasyid Ridha berusaha memasukkan pemikiran modern di alAzhar dengan memandang bahwa kamajuan umat Islam harus didasarkan penggaliannya dari al-Qur'an untuk melahirkan sains dan teknologi modern.

Rasyid Ridha memandang bahwa peradaban Barat modern didasarkan atas kemajuan ilmu pengetahuan dan teknologi. Ilmu pengetahuan dan teknologi tidak bertentangan dengan Islam. Untuk kemajuan, umat Islam harus mau menerima peradaban Barat yang ada. Barat maju, demikian menurut Rasyid Ridha, karena mereka mau mengambil ilmu pengetahuan yang dikembangkan umat Islam zaman klasik. Dengan demikian mengambil ilmu pengetahuan barat modern sebenarnya berarti mengambil kembali ilmu pengetahuan yang pernah dimiliki umat Islam (Sani, 1998: 66).

Terkait hal ini, Rasyid Ridha menganggap perlunya diadakan tafsiran modern dari al-Qur'an, yaitu tafsiran yang sesuai dengan ide-ide yang dicetuskan gurunya. Ia selalu menganjurkan kepada Muhammad Abduh untuk menulis tafsir modern namun gurunya tersebut tidak sefaham dengannya, namun Karena desakan Rayid Rida akhirnya Muhammad Abduh akhirnya setuju untuk memberikan kuliah mengenai tafsir al-Qur'an di alAzhar yang dimulai pada tahun 1899 sampai dengan meninggalnya Muhammad Abduh yakni pada tahun 1905. Dari keterangan-keterangan yang diberikan oleh guru, Rasyid Rida selalu mencatatnya dan untuk seterusnya disusun dalam bentuk karangan yang teratur selanjutnya diperiksa oleh guru dan setelah mendapat persetujuan maka karangan tersebut ia siarkan dalam Al-Manar. Setelah guru meninggal, murid meneruskan penulisan tafsir sesuai dengan jiwa dan ide yang duicetuskan guru dan Muhammad Abduh sendiri sempat memberikan tafsiran sampai dengan 
ayat 125 dari surat Al-Nisa' (jilid III dari Tafsir Al-Manar) dan yang selanjutnya adalah tafsiran murid sendiri.

Rasyid Ridha menganggap bahwa penghargaan terhadap akal terbatas, ia mengritik paham tasawuf dan tarekat yang ekstrem dan dianggap menjadi virus umat, karena ajaran inilah telah melemahkan semangat juang dan tanggung jawab mereka di dunia ini. Oleh karena itu perlu dibuka pintu ijtihad yang seluas-luasnya di kalangan umat Islam, agar mencapai kemajuan.

Ketiga, ukhuwah Islamiyyah. Sebagaimana al-Afghani, Rasyid Ridha juga melihat perlunya dihidupkan kesatuan umat Islam. Menurutnya, salah satu sebab lain bagi kemunduran umat ialah perpecahan yang terjadi di kalangan mereka. Kesatuan yang dimaksud oleh beliau bukanlah kesatuan yang didasarkan atas kesatuan bahasa atau kesatuan bangsa, tetapi kesatuan atas dasar keyakinan yang sama. Oleh karena itu ia tidak setuju dengan gerakan nasionalisme yang dipelopori Mustafa Kemal at-Taturk di Mesir dan gerakan nasionalisme Turki yang dipelopori Turki Muda. Ia menganggap bahwa faham nasionalisme bertentangan dengan ajaran persaudaraan seluruh umat Islam. Persaudaraan dalam Islam tidak kenal pada perbedaan bangsa dan bahasa, bahkan tidak kenal perbedaan tanah air.

Ini jugalah yang menjadi pandangan politik penting bagi perkembangan al-Azhar yang dimunculkan dalam pemikiran bagi para mahasiswa yang dalam bahasa Arab ukhuwah Islamiyyah. Menurutnya, salah satu penyebab kemunduran umat Islam adalah perpecahan yang terjadi di kalangan mereka sendiri, kemudian ia menyeru kepada seluruh umat Islam agar bersatu kembali di bawah satu keyakinan, satu sistem moral dan satu sistem hukum yang dilaksanakan oleh satu kekuasaan. Ia juga tidak setuju dengan gerakan nasionalisme Mustafa Kemal di Mesir dan nasionalisme bertentangan dengan persaudaraan Islam. Muhammad Rasyid Ridha tidak menginginkan negara model barat melainkan negara dalam bentuk khilafah seperti masa al-Khulafaur Rasyidin yang menjalankan adalah mujtahid dan dalam menjalankan roda pemerintahnnya ia dibantu para ulama, dengan sistem khalifah ini, ukhuwah Islamiyah dapat di wujudkan (Armando, 2005: 46).

Rasyid Ridha tidak memberikan format yang jelas bagi bentuk kesatuan yang dimaksud. Ia hanya menawarkan kekhalifahan yang sekaligus mengemban fungsi sebagai kepala negara (Parmono, 2004: 72-73). Khalifah, menurutnya, karena mempunyai kekuasaan legislatif maka harus mempunyai sifat mujtahid. Tetapi, khalifah tidak boleh bersifat absolut. Ulama merupakan pembantupembantunya yang utama dalam soal memerintah rakyat. Untuk mewujudkan kesatuan umat itu, ia pada mulanya meletakkan harapan pada kerajaan Usmani, tetapi harapan itu hilang setelah Mustafa Kamal berkuasa di Istanbul dan kemudian menghapuskan sistem pemerintahan kekhalifahan. Selanjutnya ia meletakkan harapan pada kerajaan Saudi Arabia setelah Raja Abd al-Aziz dapat merebut kekuasaan di Semenanjung Arabia.

\section{Keempat,} menambahkan kurikulum modern di al-Azhar. Rasyid Ridha memandang perlunya dilaksanakan pembaharuan dalam bidang pendidikan, ia melihat perlu ditambahkan ke dalam kurikulum alAzhar mata pelajaran seperti teologi, pendidikan moral, sosoiologi, ilmu bumi, sejarah, ekonomi, ilmu hitung, ilmu kesehatan, bahasa-bahasa asing dan ilmu mengatur rumah tangga yaitu disamping fikih, tafsir, hadits dan lain- 
lain di al-Azhar. Sekaligus melakukan penguasaan terhadap iptek untuk mengikuti kemajuan Barat (Rasjidi, 1977: 71-77).

Dalam berbagai tulisannya, Rasyid mendorong umat Islam untuk menggunakan kekayaannya dalam pembangunan lembaga-lembaga pendidikan. Menurut Rasyid, membangun lembaga pendidikan lebih baik dari membangun masjid. Baginya masjid tidaklah besar nilainya apabila orang-orang yang shalat di dalamnya hanyalah orang-orang bodoh. Dengan membangun lembaga pendidikan, kebodohan dapat dihapuskan dan dengan demikian pekerjaan duniawi dan ukhrawi akan menjadi baik. Satusatunya jalan menuju kemakmuran adalah perluasan pendidikan secara umum.

Di bidang pendidikan ia mendirikan sekolah sebagai misi Islam dengan nama Madrasah al-Dakwah wa al-Irsyad di Kairo pada tahun 1912 M. Para alumni madrasah ini disebarkan keberbagai dunia Islam. Muhammad Rasyid Ridha sebagai penggerak pembaharuan Islam yang masih condong pada ajaran-ajaran Ibnu Taimiyah. Ia sebagai penyokong aliran Wahabi, karena dalam ajaran aliran tersebut dikemukakan pengakuan bermazhab salaf yang bertujuan mengembalikan ajaran Islam kepada alQur'an dan al-Hadis (Sudarsono, 1994: 163).

\section{SIMPULAN}

Sejarah sosial pendidikan Islam era reformasi dan modern di al-Azhar dapat disimpulkan pada beberapa hal. Pertama, latar belakang sosial al-Azhar. Dinasti Fatimiyah menjadikan Mesir sebagai pusat pemerintahan. Sebagai pusat pemerintahan maka didirikanlah masjid Al-Azhar di Kairo, yang kelak menjadi lembaga pendidikan tinggi Al-
Azhar. Dinasti Fatimiyah menjadikan Al-Azhar ini propaganda ajaran Syi'ah dan lambang kepemimpinan spiritual umat Islam. Masjid ini dikembangkan fungsinya akibat banyaknya para pelajar yang ingin mendalami ilmu agama dan berdiskusi maka timbul inisiatif untuk mengembangkan masjid ini menjadi sebuah universitas yang merupakan dasar yang sangat fundamental dalam membangun paradigma pemikiran keislaman. Berdiri pula Dinasti Ayyubiyah di Mesir yang berpaham Sunni berdampak bagi perkembangan Al-Azhar. Di samping itu muncul pula Napoleon Bonaparte menguasai Mesir yang membawa peralatan perang canggih dan juga ilmu pengetahuan pada umat Islam dan berdampak bagi perkembangan AlAzhar.

Kedua, latar belakang terjadinya pembaruan di Al-Azhar karena; bergesernya paham rasional Syi'ah pada ortodoksi ideologi Sunni; invasi Napoleon Bonaparte dari Prancis yang mengalahkan Kerajaan Turki Usmani di Mesir dalam waktu yang cepat; dan persentuhan peradaban Prancis yang dibawa Napoleon pada pendidikan di Al-Azhar.

Ketiga, tokoh dan ide pembaruan di Al-Azhar di Mesir dipelopori oleh Muhammad Ali Pasya, Muhammad Abduh, dan Muhammad Rasyid Ridha yang berusaha melukakan reformasi dan modernisasi di Al-Azhar dengan mamasukkan kurikulum-kurikulum dari Barat. Umat Islam dalam pandangan mereka harus keluar dari ketertinggalan melalui pembukaan kembali pemikiran rasional dan membuka diri terhadap peradaban modern yang ada di Barat seperti yang dibawa oleh Napoleon Bonaparte dari Prancis. Wallau a'lam bi al-shawab. 


\section{DAFTAR RUJUKAN}

'Auf, Ahmad Muhammad. 1970. AlAzhar fi Alfi 'Aam. Kairo: Majma' Buhus al-Islamy.

Amin, Samsul Munir. 2009. Sejarah Peradaban Islam. Jakarta: Amzah.

Anshari, Endang Saifuddin. 1978. Kuliah al-Islam. Bandung: Pustaka Bandung.

Antonio, Muhammad Syafii. 2009. Muhammad SAW: The Super Leader Super Manager. Jakarta: Tazkia Publising.

Ash-Shayim, Muhammad. 2003. Shalahuddin al-Ayyubi: Sang Pejuang Islam. Jakarta: Gema Insani Press.

Amaliyah, Asriati. 2013. Esksistensi Pendidikan Islam di Mesir Masa Daulah Fatimiyah: Lahirnya AlAzhar, Tokoh-Tokoh Pendidikan Islam pada Masa Daulah Fatimiyah dan Pengaruhnya terhadap Dunia Islam. Jurnal Lentera Pendidikan. Vol. 16, Nomor 1.

Asrohah, Hanun. 1999. Sejarah Pendidikan Islam, cet. ke -1. Jakarta: Logos Wacana Ilmu.

Djambulati, Ali. 1987. Perbandingan Pendidikan Islam, terj. H. M. Arifin. Jakarta: Rineka Cipta.

Fazlurrahman. 1984. Islam. Bandung: Pustaka.

Gibb, H.A.R., 1992. Aliran-Aliran Modern dalam Islam. Jakarta: Rajawali Pers.

Hitti, Philip K, 2005. History of The Arabs, Terj. R. Cecep Lukman Yasin dan Dedi Slamet Riyadi. Jakarta: Serambi Ilmu Semesta.

Ibrahim, Hasan. 1989. Sejarah dan Kebudayaan Islam. terj. Djahdan Humam. Yogyakarta: Kota Kembang.

Ilahi, Kurnial. 2002. Perkembangan Modern dalam Islam. Riau: Lembaga Penelitian dan
Perkembangan Fakultas Usuluddin UIN SUSKA dan Yayasan Pusaka Riau.

Jamal, Syauqi 'Atha Allah. 1988. AlAzhar wa Daurahu as-Siyasi wa alHadhori fi Afriqiya. Kairo: anNahdhah.

Kuntowijoyo. 1991. Paradigma Islam: Interpretasi untuk Aksi, cet. ke -3. Bandung: Penerbit Mizan.

Madjid, Nurkholish. 1997. Islam Kemodernan dan Keindonesiaan. Bandung: Mizan.

Mubarok, Jaih. 2008. Sejarah Perdaban Islam, cet. ke -1. Jakarta: Pustaka Islamika.

Mughni, Syafiq A., 1997. Sejarah Kebudayaan Islam di Turki. Jakarta: Logos Wacana Ilmu.

Mujib, Abdul dan Mudzakkir, Jusuf. 2008. Ilmu Pendidikan Islam, cet. ke -2. Jakarta: Kencana

Munir, Sudarsono A., 1994. Aliran Modern dalam Islam, Jakarta: Rineka Cipta.

Nasution, Harun. 1992. Pembaharuan dalam Islam: Pemikiran dan Gerakan. Jakarta: Bulan Bintang.

Nata, Abuddin. 2004. Sejarah Pendidikan Islam pada Periode Klasik dan Pertengahan. Jakarta: Raja Grafindo Persada.

Nina M. Armando, et. al., (ed.,), Ensiklopedi Islam Jilid 1, Jakarta: Ichtiar Baru van Hoeve, 2005

Nina M. Armando, et. al., (ed.), Ensiklopedi Islam Jilid 3, Jakarta: Ichtiar Baru van Hoeve, 2005

Nina M. Aramnado, et. al., (ed.), Ensiklopedi Islam Jilid 4, Jakarta: Ichtiar Baru van Hoeve, 2005

Nina M. Armando, et. al., (ed.,), Ensiklopedi Islam Jilid 5, Jakarta: Ichtiar Baru van Hoeve, 2005

Nina M. Armando, et. al. (ed.), Ensiklopedi Islam Jilid 6, Jakarta: Ichtiar Baru van Hoeve, 2005 
Nurkholish Madjid, Islam Kemodernan dan Keindonesiaan, Bandung: Mizan, 1997, cet. ke -9

Parmono, Sjechrul Hadi. 2004. Islam dalam Lintasanm Sejarah Perpolitikan. Surabaya: Aulia.

Rahmena, Ali. 1996. Para Perintis Zaman Baru Islam. Bandung: Mizan.

Rais, Amin. 1993. Islam dan Pembaharuan. Jakarta: Rajawali Press.

Razak, Nasruddin. 1989. Dienul Islam, Bandung: al-Ma'arif Bandung.

Rasjidi. 1977. Koreksi terhadap DR. Harun Nasution tentang Islam Ditinjau dari Berbagai Aspeknya. Jakarta: Bulan Bintang.

Rokhim, "Latar Belakang Berdirinya Dinasti Ayyubiyah", www.rokhim.net.

Sani, Abdul. 1998. Lintasan Sejarah Pemikiran Perkembangan Modern dalam Islam. Jakarta: Raja Grafindo Persada.

Sharon Siddique, "Conceptualizaing Contemporary Islam: religion or Ideology", dalam, Ahmad Ibrahim, et. al., Reading on Islam in Southest Asia, (Singapura: Institute of Southeast Asian Studies, 1986

Sihbudi, M. Riza et. al., 1993. Konflik dan Diplomasi di Timur Tengah. Bandung: Eresco.

Sunanto, Musyrifah. 2007. Sejarah Islam Klasik Perkembangan Ilmu
Pengetahuan Islam. Jakarta: Kencana Prenada Media.

Suwito dan Fauzan. 2005. Sejarah Sosial Pendidikan Islam, cet. ke-1. Jakarta: Prenada Media.

Stanton, Charles Michael. 1998. Pendidikan Tinggi dalam Islam, terj. Ahmad Afandi dan Hasan Asari. Jakarta: Logos Wacana Ilmu.

Thohir, Ajid. 2009. Perkembangan Peradaban di Kawasan Dunia Islam Melacak Akar-Akar Sejarah, Sosial, Politik, dan Budaya Umat Islam. Jakarta: RajaGrafindo Persada.

Tim Penulis IAIN Syarif Hidayatullah. 2002 Ensiklopedi Islam Indonesia. Jakarta: Djambatan.

Wijaya, Cece et. al., 1992. Upaya Pembaruan dalam Pendidikan dan Pengajaran. Bandung: Remaja Rosdakarya.

Yatim, Badri. 1995. Sejarah Peradaban Islam. Jakarta: Raja Grafindo Persada.

Yunus, Muhammad. 1990. Sejarah Pendidikan Islam. Jakarta: Hidakarya Agung.

Zuhairini. 1995. Sejarah Pendidikan Islam, , cet. ke -4. Jakarta: Bumi Aksara.

Zulkarnaini, 2011. Konsep Imamah dalam Perspektif Syi'ah. Jurnal Tapis, Vol. 17, No. 13 